\title{
Minimize Rental Costs on Flowshop Scheduling
}

\author{
M Faudzi Bahari ${ }^{1)}$, Sudradjat Sudrajat ${ }^{2)}$, E Lesmana $^{2)}$ \\ ${ }^{1)}$ Master Program in Mathematics, Faculty Of Mathematics and Natural Science, Padjadjaran \\ University, Indonesia \\ ${ }^{2)}$ Department of Mathematics, Faculty of Mathematics and Natural Sciences, \\ Padjadjaran University, Indonesia \\ mfaudzibahari@gmail.com
}

(Article History： Received 28-01-2020; Accepted 24-05-2020; Published 03-06-2020)

\begin{abstract}
This paper discusses solving the problem of rental costs in a Flowshop scheduling with $n$-jobs and $\mathrm{m}$-Machines in small and medium-sized companies to minimize rental costs to be paid. The proposed method is the development of an existing method using several proven propositions. The method used is applied in a sandals company that rents 11 machines used to produce 6 types of products. The proposed method yields a rental fee of IDR 1,071,121.5.
\end{abstract}

Keywords: Flow shop; minimize rental cost; scheduling

\section{Minimisasi Biaya Sewa pada Penjadwalan Flowshop}

\section{ABSTRAK}

Paper ini membahas mengenai minimisasi biaya sewa yang harus dibayar oleh perusahaan berskala kecilmenengah yang menggunakan penjadwalan flowshop dengan n-buah pekerjaan yang dikerjakan oleh mbuah mesin pada proses produksinya. Metode yang dibuat adalah pengembangan dari metode sebelumnya yang dibuktikan dengan menggunakan beberapa proposisi pendukung. Metode ini telah diaplikasikan pada sebuah perusahaan sandal yang memproduksi 6 jenis sandal dengan menggunakan 11 mesin yang berbeda. Berdasarkan metode ini perusahaan harus membayar biaya sewa mesin sebesar Rp. 1,071,121.5.

Kata Kunci: Flow shop; minimisasi biaya sewa; penjadwalan

\section{INTRODUCTION}

Scheduling is one of the fundamental steps in a production process. Inadequate scheduling system has an impact on increasing the completion time in a production process, so the quantity of products produced is not optimal. If the company does not produce the maximum production quantity, then the number of products not fulfilled to meet consumer demand.

Besides paying attention to the production process time, the company must also consider the costs. In some small and medium companies, companies not only consider the cost of raw materials and workers, but also about the costs of renting production machinery. This happens because some companies do not have enough money to buy a production machine or do not dare to invest large amounts of money to buy a production machine. So, the solution taken is to rent a production machine. In these circumstances the company needs to optimize the time of production used to reduce production costs, especially in the cost of renting machinery.

Several previous studies have been conducted to solve this problem. Narain explained the situation in scheduling production using rental costs (Narain \& Bagga, 2005), then made several theorems in further research to get minimization of rental costs on scheduling 2 and 3 machines by finding the right time to start doing rent (Narain, 2015; Ahmad \& Khan, 2017). Gupta also conducted research on minimizing rental costs on scheduling 2 machines using the branch and bound method (Gupta, et al., 2013). In addition, recent research is about minimizing rental costs on scheduling 2 
machines by considering job-block criteria (Gupta \& Sehga, 2014). Ahmad conducted research to minimize rental costs on scheduling with m-machines and n-jobs, by sorting jobs based on the largest time on the machine with the smallest total time (Johnson, 1954).

Based on previous research, we realized that the theorems introduced by Narain could be developed to solve problems with a greater number of machines.

\section{RESEARCH METHOD}

This section contains notations, problem formulations and proposed algorithms that have been obtained from propositions that we developed based on Narain's theorem.

\section{Notations}

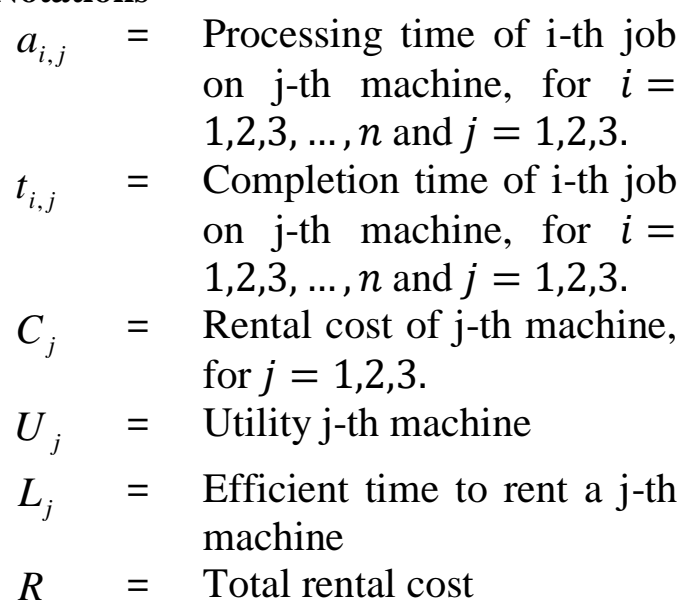

\section{Problem Formulations}

Consider the problem of scheduling flow shops with $n$-jobs and m-machines. Each machine used is a rental machine that has a fee to pay. The goal is to get a schedule to increase rental costs. So it takes a step so that the rental machine is used to be optimal so that the costs incurred are minimum. The minimum value of total cost is obtained as (Narain, 2015a):

$$
R=\sum_{i=1}^{m}\left(U_{i} \times C_{i}\right)
$$

\section{Definition (Gupta \& Sehga, 2014)}

Completion time for $i-t h$ job on machine $M_{j}$ denoted by $t_{i, j}$ and defined as:

$$
t_{i, j}=\max \left(t_{i-1, j}, t_{i, j-1}\right)+a_{i, j}
$$

where:

$t_{i, j}=$ total completion time of $i-t h$ job on $j-t h$ machine

$a_{i, j}=$ processing time of $i-t h$ job on $j-t h$ machine

Based on this definition, we develop by making two propositions that have been proven as an aid to prove that the method used can be used in accordance with mathematical rules.

\section{Proposition 1}

Compeltion time on the m-th-machine will not change while machine is rented when $L_{m}=\sum_{i=1}^{n} I_{i, m}$.

\section{Proposition 2}

If $\quad t_{n, r}-t_{1,(r-1)}=\sum_{i=1}^{n} a_{i, r} \quad$ for $\quad$ a $\quad r-t h$ machine then the use of the machine is optimal. If $t_{n, r}-t_{1,(r-1)}>\sum_{i=1}^{n} a_{i, r}$ for a $r-t h$ machine, the use of the machine is not optimal and cost minimization can be done by renting when $L_{r}$.

$L_{r}=\min \left\{Y_{k}\right\}$

With:

$Y_{k}=L_{(r+1)}-\sum_{i=1}^{k} a_{i, r}+\sum_{i=1}^{k-1} a_{1,(r+1)}++\sum_{i=1}^{k-2} a_{1,(r+2)}+\ldots+\sum_{i=1}^{k-k} a_{1,(r+k)}$

\section{Algorithm}

Step 1: Manipulating $\mathrm{m}$ machines into $2 G_{i}$ and $H_{i}$ machines using the Johnson rule extension.

Step 2: Sort jobs by using Johnson's rules.

Step 3: Create a scheduling table in the order that you have obtained.

Step 4: Check the optimality of each machine by comparing $\sum_{i=1}^{n} a_{i, j}$ with the total elapsed time. If the value is equal, then the machine is optimal and not reduction in utility machinery is necessary. If. value of the total elapsed time 
is bigger than $\sum_{i=1}^{n} a_{i, j}$, then the utility will be reduced from each machine.

Step 5: Determine the last machine rental time with the formula $L_{m}=t_{n, m}-\sum_{i=1}^{n} a_{i, m}$

Step 6: Determine the rental time for machines that need to be reduced by finding the smallest value of each $Y_{k}$.

Step 7: Create a scheduling table with the start time of the machine starting at $L_{k}$.

Step 8: Calculate the cost of rent with the formula: $R=\sum_{i=1}^{m}\left(U_{i} \times C_{i}\right)$.

\section{RESULTS AND DISCUSSION}

\section{Rental Policy}

There are several policies that can be taken. Rental policies that are commonly used are as follows:

1. The company takes rent when the production process begins and returns when the production process is complete.
2. The company takes rent when the machine is needed and returns it when the machine is no longer needed.

3. The company takes rent every time the machine is needed and returns it every time the machine is not needed.

We conducted research on a small to medium company that produces 6 types of sandals with 11 machines. All machines used in the production process have different rental prices. Our goal is to help companies choose the time they lease to save rent costs according to agreed upon rental policies.

The processing time for each type of product operated in each machine is shown in table 1 .

Table 1. Jobs and processing time for each machine

\begin{tabular}{|c|c|c|c|c|c|c|c|c|c|c|c|}
\hline \multirow[t]{2}{*}{ Job } & \multicolumn{11}{|c|}{ Machine } \\
\hline & $\mathbf{A}$ & B & $\mathbf{C}$ & D & $\mathbf{E}$ & $\mathbf{F}$ & G & $\mathbf{H}$ & I & $\mathbf{J}$ & $\mathbf{K}$ \\
\hline 1 & 5 & 10.7 & 21.3 & 48 & 11.8 & 33.3 & 14.7 & 1 & 5.3 & 6.4 & 20 \\
\hline 2 & 7.5 & 16 & 32 & 72 & 17.6 & 50 & 22 & 1 & 8 & 9.6 & 30 \\
\hline 3 & 12.5 & 26.7 & 23.3 & 16.7 & 29.4 & 83.3 & 36.7 & 2 & 13.3 & 16 & 50 \\
\hline 4 & 12.5 & 26.7 & 53.3 & 120 & 29.4 & 83.3 & 36.7 & 2 & 13.3 & 16 & 50 \\
\hline 5 & 2.5 & 5.3 & 10.7 & 24 & 5.9 & 16.7 & 7.3 & 1 & 2.7 & 3.2 & 10 \\
\hline 6 & 10 & 21.3 & 42.7 & 96 & 23.5 & 66.7 & 29.3 & 2 & 10.7 & 12.8 & 40 \\
\hline
\end{tabular}

Rental costs per unit time for each machines are shown by table 2 .

Based on the algorithm previously described, we made 2 fictional machines representing time on 11 actual machines using the extended Johnson Rule.

Step 1: Reduced problem on the two fictitious with processing times (table 3 ).

Based on table 3 , it can be seen that the smallest processing time is when the 5 th job is on the first fictional machine. The next smallest processing time in sequence is the $1 \mathrm{st}$ job on the first fictional machine, the 2 nd job on the first fictional machine, the 3 rd job on the first fictional machine, the 6th job on the first fictional machine and the 4 th job on the first fictional machine .

Step 2: We have to sorting jobs by using Johnson's rules and get optimal sequence. The sequence with minimum elapsed time has obtained by johnson rules is 5-1-2-3-6-4. The sequence obtained is the optimal order according to Johnson's rules.

Table 2. Jobs and processing time for each machine 


\begin{tabular}{cc}
\hline Machine & Rental Cost \\
\hline 1 & 4400 \\
2 & 2500 \\
3 & 800 \\
4 & 170 \\
5 & 200 \\
6 & 145 \\
7 & 290 \\
8 & 1000 \\
9 & 180 \\
10 & 120 \\
11 & 200 \\
\hline
\end{tabular}

Step 3: Next, we make scheduling in the order we got from the Johnson rules. Scheduling in the order obtained is shown in table 4.
Table 3. Process time on fictious machine $G i$ and $H_{\mathrm{i}}$

\begin{tabular}{ccc}
\hline Job & $G_{i}$ & $H_{i}$ \\
\hline 1 & 157.5 & 172.5 \\
2 & 235.7 & 258.2 \\
3 & 259.9 & 297.4 \\
4 & 393.2 & 430.7 \\
5 & 79.3 & 86.8 \\
6 & 315 & 345 \\
\hline
\end{tabular}

Step 4: We will compare machine utilities with total elapsed time for each machines. A comparison between machine utilities with total elapsed time shown in the table 5.

Table 4. In-Out Table By Using Johnson Rules

\begin{tabular}{|c|c|c|c|c|c|c|c|c|c|c|c|}
\hline \multirow{2}{*}{ Job } & \multicolumn{11}{|c|}{ Machine } \\
\hline & $\mathbf{A}$ & B & C & D & $\mathbf{E}$ & F & G & H & I & $\mathbf{J}$ & $\mathbf{K}$ \\
\hline 5 & $0-2.5$ & $2.5-7.8$ & $7.8-18.5$ & $18.5-42.5$ & $42.5-48.4$ & $48.4-65.1$ & $65.1-72.4$ & $72.4-73.4$ & $73.4-76.1$ & $76.1-79.3$ & $79.3-89.3$ \\
\hline 1 & $2.5-7.5$ & $7.8-18.5$ & $18.5-39.8$ & $42.5-90.5$ & $90.5-102.3$ & $102.3-135.6$ & $135.6-150.3$ & $150.3-151.3$ & $151.3-156.6$ & $156.6-163$ & 163-183 \\
\hline 2 & $7.5-15$ & $18.5-34.5$ & $39.8-71.8$ & $90.5-162.5$ & $162.5-180.1$ & $180.1-230.1$ & $230.1-252.1$ & $252.1-253.1$ & $253.1-261.1$ & $\begin{array}{l}261.1- \\
270.7\end{array}$ & $\begin{array}{l}270.7- \\
300.7\end{array}$ \\
\hline 3 & $15-27.5$ & $34.5-61.2$ & $71.8-95.1$ & $162.5-179.2$ & $180.1-209.5$ & $230.1-313.4$ & $313.4-350.1$ & $350.1-352.1$ & $352.1-365.4$ & $\begin{array}{l}365.4- \\
381.4\end{array}$ & $\begin{array}{l}381.4- \\
431.4\end{array}$ \\
\hline 6 & $27.5-37.5$ & $61.2-82.5$ & $95.1-137.8$ & $179.2-275.2$ & $275.2-298.7$ & $313.4-380.1$ & $380.1-409.4$ & $409.4-411.4$ & $411.4-422.1$ & $\begin{array}{l}422.1- \\
434.9\end{array}$ & $\begin{array}{l}434.9- \\
474.9\end{array}$ \\
\hline 4 & $37.5-50$ & $82.5-109.2$ & $137.8-191.1$ & $275.2-395.2$ & $395.2-424.6$ & $424.6-507.9$ & $507.9-544.6$ & $544.6-546.6$ & 546.6-559.9 & $\begin{array}{l}559.9- \\
575.9\end{array}$ & $\begin{array}{l}575.9- \\
625.9\end{array}$ \\
\hline
\end{tabular}

Based on table 5 it is known that the utility machines E, F, G, H, I, J and K can be reduced. This can be known because Total Elapsed Time $>\sum_{i=1}^{n} a_{i, j}$, so we can reduce it.

The first step in the process of reducing rental costs is to determine the efficient time to rent the last machine.

Step 5: We will calculate the efficient time for take a rent the last machine.

$$
\begin{aligned}
& L_{m}=t_{n, m}-\sum_{i=1}^{n} a_{i, m} \\
& L_{11}=625.9-200 \\
& L_{11}=425.9
\end{aligned}
$$

So, we can take rent for the last machine or the 11th engine when the production process has been going on for 425.9 minutes.

Step 6: Based on calculations using proposition 2, the results shown in table 6 .

Based on table 6, we get information that the fifth machine will start to be rented when the production process has gone on for 158.9 minutes. While the sixth machine will start to be rented when the production process has been going on for 164.8 minutes. The seventh machine will be rented when the production process has been running for 347.5 minutes. Efficiency time machines for leasing on the eighth, ninth and tenth machines will be leased in a row when the production process has been going on for 416.9 minutes, 417.9 minutes, and 422.7 minutes. 
Table 5. Comparison Total Elapsed Time with $\sum_{i=1}^{n} a_{i, j}$

\begin{tabular}{cll}
\hline Machine & $\begin{array}{l}\text { Total } \\
\text { Elapsed } \\
\text { Time }\end{array}$ & $\sum_{i=1}^{n} a_{i, j}$ \\
\hline A & 50 & 50 \\
B & 106.7 & 106.7 \\
C & 183.3 & 183.3 \\
D & 376.7 & 376.7 \\
E & 382.1 & 117.6 \\
F & 459.5 & 333.3 \\
G & 479.5 & 146.7 \\
H & 474.2 & 9 \\
I & 486.5 & 53.3 \\
J & 499.8 & 64 \\
K & 546.6 & 200 \\
\hline & & \\
\hline
\end{tabular}

Table 6. Efficient Time For Renting Machines

\begin{tabular}{lc}
\hline Machine & $\min \left\{Y_{k}\right\}$ \\
\hline E & 158.9 \\
F & 164.8 \\
G & 347.5 \\
H & 416.9 \\
I & 417.9 \\
J & 422.7 \\
K & 425.9 \\
\hline
\end{tabular}

Step 7: Scheduling in the order obtained is shown in table 7.

Table 7. In-Out Table By Using Johnson Rules

\begin{tabular}{|c|c|c|c|c|c|c|c|c|c|c|c|}
\hline Jo b & $\mathbf{A}$ & B & C & D & $\mathbf{E}$ & $\mathbf{F}$ & G & $\mathbf{H}$ & I & $\mathbf{J}$ & $\mathbf{K}$ \\
\hline 5 & $0-2.5$ & $2.5-7.8$ & $7.8-18.5$ & $18.5-42.5$ & $\begin{array}{l}158.9- \\
164.8\end{array}$ & $\begin{array}{l}164.8- \\
181.5\end{array}$ & $\begin{array}{l}347.5- \\
354.8\end{array}$ & $\begin{array}{l}416.9- \\
417.9\end{array}$ & $\begin{array}{l}417.9- \\
420.6\end{array}$ & $\begin{array}{l}422.7- \\
425.9\end{array}$ & $\begin{array}{l}425.9- \\
435.9\end{array}$ \\
\hline 1 & $2.5-7.5$ & $7.8-18.5$ & $18.5-39.8$ & $42.5-90.5$ & $\begin{array}{l}164.8- \\
176.6\end{array}$ & $\begin{array}{l}181.5- \\
214.8\end{array}$ & $\begin{array}{l}354.8- \\
369.5\end{array}$ & $\begin{array}{l}417.9- \\
418.9\end{array}$ & $\begin{array}{l}420.6- \\
425.9\end{array}$ & $\begin{array}{l}425.9- \\
432.3\end{array}$ & $\begin{array}{l}435.9- \\
455.9\end{array}$ \\
\hline 2 & $7.5-15$ & $18.5-34.5$ & $39.8-71.8$ & $90.5-162.5$ & $\begin{array}{l}176.6- \\
194.2\end{array}$ & $\begin{array}{l}214.8- \\
264.8\end{array}$ & $\begin{array}{l}369.5- \\
391.5\end{array}$ & $\begin{array}{l}418.9- \\
419.9\end{array}$ & $\begin{array}{l}425.9- \\
433.9\end{array}$ & $\begin{array}{l}433.9- \\
443.5\end{array}$ & $\begin{array}{l}455.9- \\
485.9\end{array}$ \\
\hline 3 & $15-27.5$ & $34.5-61.2$ & $71.8-95.1$ & $\begin{array}{l}162.5- \\
179.2\end{array}$ & $\begin{array}{l}194.2- \\
223.6\end{array}$ & $\begin{array}{l}264.8- \\
348.1\end{array}$ & $\begin{array}{l}391.5- \\
428.2\end{array}$ & $\begin{array}{l}428.2- \\
430.2\end{array}$ & $\begin{array}{l}433.9- \\
447.2\end{array}$ & $\begin{array}{l}447.2- \\
463.2\end{array}$ & $\begin{array}{l}485.9- \\
535.9\end{array}$ \\
\hline 6 & $\begin{array}{l}27.5- \\
37.5\end{array}$ & $61.2-82.5$ & $95.1-137.8$ & $\begin{array}{l}179.2- \\
275.2\end{array}$ & $\begin{array}{l}275.2- \\
298.7\end{array}$ & $\begin{array}{l}348.1- \\
414.8\end{array}$ & $\begin{array}{l}428.2- \\
457.5\end{array}$ & $\begin{array}{l}457.5- \\
459.5\end{array}$ & $\begin{array}{l}459.5- \\
470.2\end{array}$ & $470.2-483$ & $\begin{array}{l}535.9- \\
575.9\end{array}$ \\
\hline 4 & $37.5-50$ & $\begin{array}{l}82.5- \\
109.2 \\
\end{array}$ & $\begin{array}{l}137.8- \\
191.1 \\
\end{array}$ & $\begin{array}{l}275.2- \\
395.2 \\
\end{array}$ & $\begin{array}{l}395.2- \\
424.6 \\
\end{array}$ & $\begin{array}{l}424.6- \\
507.9 \\
\end{array}$ & $\begin{array}{l}507.9- \\
544.6 \\
\end{array}$ & $\begin{array}{l}544.6- \\
546.6 \\
\end{array}$ & $\begin{array}{l}546.6- \\
559.9 \\
\end{array}$ & $\begin{array}{l}559.9- \\
575.9 \\
\end{array}$ & $\begin{array}{l}575.9- \\
625.9 \\
\end{array}$ \\
\hline
\end{tabular}

Step 8:

$$
\begin{aligned}
& R=\sum_{i=1}^{m}\left(U_{i} \times C_{i}\right) \\
& R=1071121.5
\end{aligned}
$$

By using the proposed method the company can find out the most efficient time to lease the machine, this results in the company being able to adopt a second type of rental policy, which is to rent when the machine is needed and return it when the machine is no longer needed. Thus, the company only has to pay a rental fee of IDR $1,071,121.5$. If the company does not know the efficient time to lease the machine, the company is forced to take the lease of the machine when the first job has been completed on the previous machine and return when the last job has been produced on the machine. If this happens the company must pay rent of IDR 1,710,597.5. Based on these facts, the proposed method can reduce costs by IDR 639,476 . This can happen because less time using the machine will automatically reduce the rental costs that must be incurred.

\section{CONCLUSIONS}

We have developed heuristic procedures for $n$-job scheduling and $m$ machine scheduling. We get a schedule with an efficient rental time so that we can minimize costs incurred by the company. This method is very easy to implement. This will also help companies solve problems related to assisting them in the decision making process. 


\section{Acknowledgements}

The authors thank you to all those who have helped in this research. Special thanks are given to $\mathrm{CV}$. SAMHARI which has allowed the author to retrieve data.

\section{REFERENCES}

Gupta, D. \& P. Sehga. 2014. Unavailability in nx2 Flow Shop Scheduling To Minimize Rental Cost With Job-Block Criteria. International Journal of Advanced Research in Science, Engineering and Technology, 69756981.

Gupta, D., P. Singla \& S. Bala. 2013. Minimize the rental cost in two stage flow shop scheduling problem in which setup time separated from processing time with branch and bound technique. International Journal of Emerging Technology and Advanced Engineering, 315-320.

Narain, L \& P.C. Bagga P.C. 2005. Scheduling problems in rental situation. Bulletin of pure and Applied sciences: Section E. Mathematics and statistics, 24.
Narain, L. 2015. Optimize Renting Times of Machines in Flow-Shop Scheduling. International Journal of Engineering and Applied Sciences (IJEAS), 2(5): 8488.

Narain, L. 2015a. Minimizing Rental Cost In Three-Machine Flowshop Problems. International Journal of Innovative Research in Computer Science \& Technology (IJIRCST), 3(3):39-42.

Ahmad, Q.S., M.H. Khan. 2017. N-Jobs And M-Machines Flowshop Scheduling To Minimize The Rental Cost. International Journal of Technical Research and Applications, Special Issue 42 (AMBALIKA): 88-90.

Johnson, S.M. 1954. Optimal two and three stage production schedule with set up times included. Naval Research Logistic, 1(1):61-64. 